\title{
EFFECT OF INCORPORATION OF CORN BYPRODUCTS ON QUALITY OF PAN BREAD FROM WHEAT FLOUR
}

\author{
El-Tellawy, F. M. ${ }^{(1)}$; Soliman, S. A. ${ }^{(2)}$ and Shaltout, M. M.
}

1) Department of Agricultural Sciences, Institute of Environmental Studies and Research, Ain shams University 2) Institute of Food Technology, Agricultural Research Center

\begin{abstract}
In the present study, corn milling by-products especially with high protein or fiber content (i.e. corn and corn gluten meal) were used in replacing part of wheat flour to the production of pan bread. The effect of blending level $(0,5,10,15$ and $20 \%)$ of corn bran, corn gluten meal and mix of them with wheat flour on the physico-chemical properties (protein, crude fiber, fat, ash and total carbohydrates), baking properties of pan bread were investigated. Blending of wheat flour and corn gluten meal and mix of (corn bran, corn gluten meal) significantly increased the protein, dietary fiber, fat and ash contents of pan bread samples, while blending of corn bran increased dietary fiber, fat and ash contents of pan bread. Blending of wheat flour and corn by-products especially corn bran decreased total carbohydrates and energy (Energy cal./100gm). Breads from mix of (corn bran, corn gluten meal) blends had higher loaf volume as compared to corn bran and corn gluten meal pan breads. Acceptable pan bread products could be produced by blending corn byproducts with wheat up to $20 \%$ level.

Keywords: Corn bran. Corn Gluten meal. Wheat flour. Pan bread.

Corn is processed either by wet or dry milling to separate the fractions. Byproducts like bran, germ and gluten are used for animal feed only. The utilization of these byproducts for human consumption is an additional nutritional source and is profitable. Neuman and Wall (1984) and Springsteen et al. (1977) reported that these byproducts have substantial amount of fiber, protein and minerals. Polizotto et al. (1983) reported that corn bran had 5.0\% protein, $0.5 \%$ fat, $17.7 \%$ non fiber carbohydrate, $0.5 \%$ ash and $76.3 \%$ ENDF (Enzymatic neutral detergent fiber) and $86.4 \%$ EIR (Enzymatic Indigestible residue) and $7.7 \%$ moisture. Corn gluten is the concentrated protein co-
\end{abstract}


product ( $70 \%$ protein, db) obtained from wet milling of corn after the germ, oil, bran and starch are extracted. It had $69.4 \%$ protein, $4.3 \%$ fat, $17.5 \%$ starch, $0.6 \%$ fiber, $1.9 \%$ ash and $7.3 \%$ carbohydrate (Neuman and Wall 1984). Purich et al. (1989) also reported a high level of phosphorus, iron and calcium in corn germ.

Corn Gluten Meal is a high protein concentrate typically supplied at a $60 \%$ protein, $2.5 \%$ fat and $1 \%$ fiber. It is a valuable source of methionine. Corn gluten meal also has a level of xanthophylls, which offers the poultry feed formulators an efficient yellow pigmenting ingredient. Corn gluten meal also is an excellent cattle feed providing a high level of rumen bypass protein (Minnesota Nutrition Conference, 2001).

Corn bran is the tough fibrous outer layer or hull of the corn kernel, also known as the pericarp. Corn bran constitutes approximately $5.3 \%$ of the corn kernel. Corn fiber is a lignocellulosic material which is a heterogeneous complex of lignin and carbohydrate polymers (Gaspar, et al. 2007). The major components of the corn fiber are hemicelluloses (35\%), cellulose $(18 \%)$, and other starch (20\%). Cellulose is a glucose polymer with a specific structure that makes it water insoluble and resistant to depolymerization.

Corn fiber is a by-product of the corn milling industry which has long been used in livestock feed, but has the potential to be a source of dietary fiber which could be added to human foods. Some processing methods result in a product that leaves a gritty texture in the finished food product that subsequently results in degradation of the dough properties. (Inglett, 2005).

Sharma, et al., (2012), reported that blending of corn bran, defatted germ and gluten at 5 and $10 \%$ with wheat flour resulted in satisfactory bread, cookie, and muffin score and significantly increased the protein, crude fiber, phosphorus, iron and calcium contents.

\section{MATERIALS AND METHODS}

\section{* Materials:}

1- Corn by-products: Samples of corn by-products (corn bran and corn gluten meal) were obtained from Starch and Glucose Factory, Cairo, Egypt. 
2-Wheat flour: Wheat flour (72\% extraction) was obtained from south Cairo Mills Company, Cairo, Egypt.

* Methods:

1- Production of feed co-products from corn wet-milling was as the follow:

- The corn is sampled and quality approved.

- The corn is cleaned.

- The corn is soaked in steep tanks for $30-50$ hours at $120-130^{\circ} \mathrm{F}$ in a dilute sulfur dioxide solution, this controlled process results in the softening of the corn kernels.

- Water is later evaporated to concentrate soluble nutrients, to become (Condensed Corn Fermented Extractives).

- Corn germ is removed from the water soaked kernel.

- The germ is further processed to recover the oil.

- The remaining portion of the germ, (Corn Germ Meal, wet or dried), is collected for feed use.

- After the germ has been removed, the rest of the corn kernel is screened to remove the bran leaving the starch and gluten protein to pass though the screens.

- The bran is combined with other co-product streams to produce (Corn Gluten Feed). 


\section{Production Process}

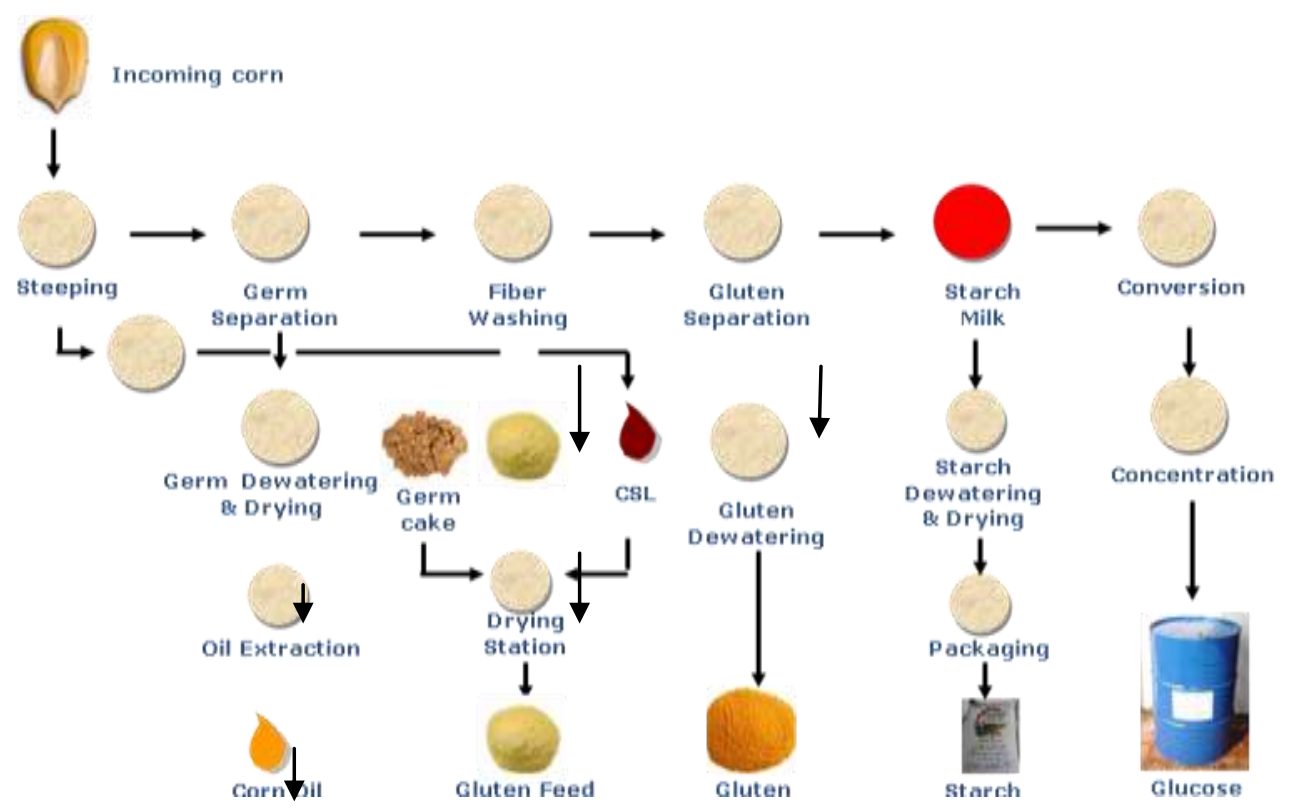

Fig.(1): Wet-milling Process of corn grains

- This starch and gluten slurry is sent to centrifugal separators, which causes the lighter gluten protein to float to the top and the heavier starch to the bottom. The gluten protein is concentrated and dried to form (Corn Gluten Meal, a $60 \%$ protein).

- Starch is washed and dried, or modified and dried and marketed to the food, paper and textile industries, or can be processed into sweeteners or ethanol.

- Wet-milling co-products represent about $25-30 \%$ of the corn processed.

- Corn bran and corn gluten meal were grinded and sifted to obtain fine particles powder of products. 
2- Blending of samples: Wheat flour was replaced with corn bran and corn gluten meal at different levels $(0,5,10,15$ and $20 \%)$.

3- Baking properties of blends: were assessed by preparing pan bread.

4- Chemical analysis of raw materials:

- Moisture, crude protein, ether extract, total ash and crude fiber contents of the materials under study were determined according to the methods described in A.O.A.C. (2005). All analysis was carried out in triplicate.

- Total dietary fiber (TDF) content was analyzed by the gravimetric method of the AOAC (2005) (method 43.A14-43.A20) based on digestion of the sample with a heat-stable $\alpha$-amylase, protease and amyloglucosidase. The results were corrected for undigested protein (Kjeldahl $\mathrm{N} \times 6.25)$ and ash (ignition at $525^{\circ} \mathrm{c}$ for $8 \mathrm{hr}$ ) associated with the fiber.

- Determination of total carbohydrate was calculated by differences.

- Determination of total calories: Total calories were determined as mentioned by Dougherty et al., (1988) according to the following equation:-

$\mathrm{E}=4(\%$ protein + carbohydrates $)+9(\%$ fat $)$.

Where: E=energy as calories per 100 gram of foods.

5 - Rheological properties:

- Farinograph test: Farinograph test was carried out to determine the water absorption arrival time, dough development time, dough stability and dough weakening of the resultant after $12 \mathrm{~min}$. according to the method described in AACC (2002).

- Extensograph test: Extensograph test was carried out to determine under curve with planimeter and report in $(\mathrm{cm} 2)$ extensibility $(\mathrm{mm})$, maximum 
resistance to extension (B.U.) and proportional number according to the method described in the AACC (2002).

6 - Preparation of pan bread: Samples were prepared by straight dough method as described in AACC (2002). The control of pan bread recipe was used after replaced the wheat flour with corn bran and corn gluten meal or mix of them at levels $0,5,10,15$ and $20 \%$.

7 - Sensory evaluation of pan bread: Types of pan bread were evaluated for their sensory characteristics by ten panelists from the staff of Bread and Pastry, Res. Dept., Food Technology Res. Institute, Agric. Res. Center, Giza.

- The scoring scheme was established as mentioned AACC (2002). as follows:-

Characteristics

- Appearance

- Color of crust

- Color of crumb

- Crumb texture

○ Flavor

- Taste

- Over all acceptability
Maximum score 20 15 15 15 15 20 100

- The average of total score was converted to a descriptive category as follows:-
- Very good
$90-100$
Good
$80-89$ 
- Satisfactory

- Questionable
$70-79$

less than 70

8 - Statistical analysis: Data of the sensory evaluation of cakes were analyzed by the Analysis of variance (ANOVA) and using the statistical package for the social (SPSS, Chicago); $<<0.05$ was considered significant. Specific differences between treatments were determined by LSD test for each attribute. Results were tested for degree of significant level at $\mathrm{p}<0.05$ according the methods of Hills (1966).

\section{RESULTS AND DISCUSSION}

1- Proximate chemical composition of materials: Wheat flour $72 \%$ ext. and corn by-products i.e. corn bran and corn gluten meal were analyzed for moisture, protein, ether extract, ash, total dietary fiber and total carbohydrates. The obtained results are shown in Table (1).

Table (1): The proximate composition (\%) of the raw materials (On dry weight basis).

\begin{tabular}{|l|c|c|c|c|c|c|c|}
\hline \multirow{2}{*}{ Samples } & & \multicolumn{6}{|c|}{ On dry weight basis } \\
\cline { 2 - 8 } & $\begin{array}{c}\text { Moisture } \\
\%\end{array}$ & $\begin{array}{c}\text { Crude } \\
\text { Protein } \\
\%\end{array}$ & $\begin{array}{c}\text { Crude } \\
\text { lipid } \\
\%\end{array}$ & $\begin{array}{c}\text { Total } \\
\text { dietary } \\
\text { fiber } \\
\%\end{array}$ & $\begin{array}{c}\text { Ash } \\
\%\end{array}$ & $\begin{array}{c}\text { Total } \\
\text { Carbohydr } \\
\text { ates } \\
\%\end{array}$ & $\begin{array}{c}\text { Caloric } \\
\text { (k.cal } \\
\text { per100) }\end{array}$ \\
\hline \hline $\begin{array}{l}\text { Wheat flour } \\
72 \% \text { Ext. }\end{array}$ & $10.84 \mathrm{c}$ & $11.96 \mathrm{~b}$ & $0.88 \mathrm{c}$ & $0.70 \mathrm{c}$ & $0.56 \mathrm{c}$ & $85.9 \mathrm{a}$ & 399.36 \\
\hline $\begin{array}{l}\text { Corn gluten } \\
\text { meal }\end{array}$ & $11.67 \mathrm{~b}$ & $68.44 \mathrm{a}$ & $6.08 \mathrm{a}$ & $2.75 \mathrm{~b}$ & $1.58 \mathrm{~b}$ & $21.15 \mathrm{c}$ & 413.08 \\
\hline Corn fiber & $12.04 \mathrm{a}$ & $9.24 \mathrm{c}$ & $3.98 \mathrm{~b}$ & $59.61 \mathrm{a}$ & $4.05 \mathrm{a}$ & $23.12 \mathrm{~b}$ & 165.26 \\
\hline L.S.D & 0.10 & 0.11 & 0.09 & 0.70 & 0.014 & 0.95 & \\
\hline \hline
\end{tabular}

Results presented in Table (1) showed that corn bran had the highest ash content $(4.05 \%)$ followed by corn gluten meal (1.58) and finally wheat flour $(0.56 \%)$. Concerning protein content, corn gluten meal was the highest 
among corn milling by-products in protein content (68.44\%). Wheat flour had protein content $10.87 \%$, while corn bran was the lowest $(9.24 \%)$. For fat content (ether extract), corn gluten meal contained the highest percentage of ether extract $(6.08 \%)$. On the other hand, wheat flour had the lowest fat content $(0.88 \%)$.

Total dietary fiber content of raw materials could be arranged in the following descending order: 59.61, 2.75 and 0.70 percent for corn bran, corn gluten meal and finally wheat flour, respectively.

Carbohydrate content was determined by the difference between 100 and the summation of protein, fat, ash and Total dietary fiber. Data showed that corn bran and corn gluten meal contained the lowest level of carbohydrates $(23.12 \%)$ and $(21.15 \%)$, respectively, while wheat flour was the highest $(85.9 \%)$ These results could be due to the highest content of dietary fiber and protein content of corn byproducts).

The above results are found to be closely near that obtained by (Dowedar, 2001; Abd el Khalek, 2003; Bedeir, 2004; Ibrahim, 2011 and Nasr, 2012) who reported that the composition of wheat flour from 10.93 to $12.5 \%$ protein, from 0.39 to $1.13 \%$ fat, from 0.61 to $1.16 \%$ crud fiber, from 0.47 to $0.56 \%$ ash and from 86.08 to $87.20 \%$ total carbohydrates.

The results of chemical analysis of corn gluten meal are found to be closely near that obtained by (Younis, 1992; Harstad and Pretlaken, 2001; Shukla and Cheryan,2001; Farag, 2003; Hill, 2004; Erickson, 2006; Davis, 2009 and Nasr, 2012) who reported that the composition of corn gluten meal 
from 59.1 to $69.8 \%$ protein, from 2.5 to $6.38 \%$ fat, from 1.02 to $3.17 \%$ crud fiber, from 1.1 to $3.35 \%$ ash and from 20.0 to $36.63 \%$ total carbohydrates.

From Minnesota Nutrition Conference, (2001): Corn gluten meal is a high protein concentrate typically supplied at a $60 \%$ protein, $2.5 \%$ fat and $1 \%$ fiber.

Polizotto et al. (1983) reported that corn bran had 5.0\% protein, $0.5 \%$ fat, $17.7 \%$ non fiber carbohydrate, $0.5 \%$ ash and 76.3\% ENDF (Enzymatic neutral detergent fiber) and $86.4 \%$ EIR (Enzymatic Indigestible residue) and $7.7 \%$ moisture.

2- Rheological properties of dough produced from wheat flour (72\% ext.), corn gluten meal, corn fiber, and mix of them blends.

a) Farinograph parameters: The effect of replacing wheat flour with different levels of corn gluten meal, corn fiber, and mix of them, on mixing dough properties are presented in table (2)

Data present in Table (2) show that the water absorption of the control (wheat flour $72 \%$ showed a value of $69.1 \%$, while wheat flour blended with 5n 10, 15 and $20 \%$ corn gluten meal showed values ranged of $62.2-65.0 \%$, this gradual decrease may be due to the dilution of wheat gluten protein content in the blends Uthayakumaran et al. (1999) reported that it was known that water absorption capacity of flour varied with both protein content and quality. Whereas the same results indicated that water absorption and arrival time increased due to the increase wheat flour substitution levels with corn fiber or with the mix of (corn gluten meal+ corn fiber). This might be due to the increase in the fiber levels in corn fiber blends and high water absorption of fiber. 
Arrival time showed values were ranged from 0.5 to $3.5 \mathrm{~min}$ for wheat flour and blendes. Dough development time showed values were ranged from 1.5 to 4.0 min for wheat flour and blendes.

Dough stability increased due to the increase wheat flour substitution levels with corn fiber, while it decreased as wheat flour substitution levels with corn gluten meal or with the mix of (corn gluten meal+ corn fiber). Degree of weakening values were decreased as the levels wheat flour substitution levels with corn fiber were increased, while it increased as wheat flour substitution levels with corn gluten meal or with the mix of (corn gluten meal+ corn fiber). This might be due to increasing of fibrous materials which contribute gluten net development (Nasr, 2012).

Table (2): Farinograph properties of dough produced from wheat flour (WF) 72\% ext., blended with corn gluten meal, corn fiber, and mix of them.

\begin{tabular}{|c|c|c|c|c|c|c|}
\hline \multicolumn{2}{|c|}{ Samples } & $\begin{array}{c}\text { Water } \\
\text { absorption } \\
\%\end{array}$ & $\begin{array}{c}\text { Arrival } \\
\text { time } \\
(\text { min })\end{array}$ & $\begin{array}{c}\text { Dough } \\
\text { development } \\
\text { (min) }\end{array}$ & $\begin{array}{c}\text { Stability } \\
\text { (min) }\end{array}$ & $\begin{array}{c}\text { Degree of } \\
\text { softening } \\
\text { (B.U) }\end{array}$ \\
\hline \multicolumn{2}{|c|}{ control } & 69.1 & 1.50 & 3.0 & 10.0 & 55 \\
\hline $5 \%$ & \multirow{4}{*}{ 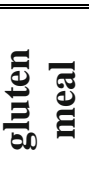 } & 65.0 & 1.50 & 2.50 & 6.0 & $\overline{770}$ \\
\hline $10 \%$ & & 63.5 & 1.50 & 2.50 & 5.50 & 95 \\
\hline $15 \%$ & & 62.8 & 0.50 & 1.00 & 6.00 & 110 \\
\hline $20 \%$ & & 62.2 & 1.50 & 2.50 & 6.50 & 110 \\
\hline $5 \%$ & \multirow{4}{*}{ 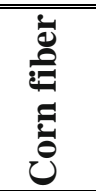 } & $\overline{71.0}$ & 2.00 & 2.50 & 10.5 & 40 \\
\hline $10 \%$ & & 76.0 & 1.00 & 1.50 & 11.5 & 30 \\
\hline $15 \%$ & & 75.0 & 1.00 & 1.50 & 12.5 & 20 \\
\hline $20 \%$ & & 81.5 & 2.00 & 2.50 & 13.0 & 20 \\
\hline $5 \%$ & \multirow{4}{*}{$\stackrel{x}{z}$} & 69.0 & 1.5 & 2.00 & 7.50 & 110 \\
\hline $10 \%$ & & 72.5 & 3.50 & 4.0 & 6.00 & 90 \\
\hline $15 \%$ & & 76.5 & 3.50 & 4.00 & 8.00 & 70 \\
\hline $20 \%$ & & 79.0 & 2.50 & 3.00 & 9.00 & 50 \\
\hline
\end{tabular}


b) Extensograph parameters: The effect of replacing wheat flour with different $0,5,10,15$ and 20\% levels of corn fiber, corn gluten meal and mix of (corn gluten meal+ corn fiber) on the Extensograph parameters are presented in table (3).

Table (3): Extensograph properties of dough produced from wheat flour (WF) $72 \%$ ext., blended with corn gluten meal, corn fiber, and mix of them.

\begin{tabular}{|c|c|c|c|c|c|}
\hline \multicolumn{2}{|c|}{ Samples } & $\begin{array}{c}\text { Elasticity } \\
\text { (B.U) }\end{array}$ & $\begin{array}{c}\text { Extensibility } \\
(\mathbf{m m})\end{array}$ & P. N & $\begin{array}{l}\text { Energy } \\
\text { (C m2) }\end{array}$ \\
\hline \multicolumn{2}{|c|}{ control } & 685 & 142 & 4.82 & 98 \\
\hline $5 \%$ & \multirow{4}{*}{ 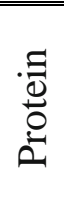 } & 750 & 100 & 7.50 & 106 \\
\hline $10 \%$ & & 650 & 95 & 6.84 & 85 \\
\hline $15 \%$ & & 480 & 130 & 3.69 & 74 \\
\hline $20 \%$ & & 470 & 85 & 5.52 & 42 \\
\hline $5 \%$ & \multirow{4}{*}{$\frac{\bar{\Delta}}{\dot{0}}$} & 260 & 110 & 2.36 & 35 \\
\hline $10 \%$ & & 190 & 110 & 1.74 & 40 \\
\hline $15 \%$ & & 200 & 140 & 1.44 & 33 \\
\hline $20 \%$ & & 100 & 100 & 1.00 & 23 \\
\hline $5 \%$ & \multirow{4}{*}{$\stackrel{x}{\Sigma}$} & 220 & 150 & 1.46 & 61 \\
\hline $10 \%$ & & 280 & 110 & 3.55 & 39 \\
\hline $15 \%$ & & 130 & 80 & 1.62 & 31 \\
\hline $20 \%$ & & 90 & 120 & 0.75 & 24 \\
\hline
\end{tabular}

Extensograph results indicated that dough elasticity (resistance to extension), dough extensibility and energy were decreased with each increment of wheat replacement with corn fiber, corn gluten meal or with mix of (corn gluten meal+ corn fiber). From the results it could be observed that flour replacement was deteriorative to dough properties, which is related to the protein quantity and quality. Proportional number $\mathrm{R} / \mathrm{E}$ values were 
J. Environ. Sci.

Institute of Environmental Studies and Research - Ain Shams University

ranged from 0.75 to 7.5 , the results are found to be closely near that obtained by (Nasr, 2012)

3- Sensory evaluation: Baking quality and sensory evaluation of pan bread prepared with varying levels of corn fiber, corn gluten meal or with mix of (corn gluten meal+ corn fiber) blends are shown in table (4).

Table (4): Sensory characteristics and physical properties of pan bread produced from wheat flour (WF) $72 \%$ ext., blended with corn gluten meal, corn fiber, and mix of them on sensory evaluation of pan bread.

\begin{tabular}{|c|c|c|c|c|c|c|c|c|}
\hline \multicolumn{2}{|r|}{ Addition percent } & $\begin{array}{c}\text { General } \\
\text { Appearance } \\
20\end{array}$ & $\begin{array}{l}\text { Crust } \\
\text { color } \\
15\end{array}$ & $\begin{array}{l}\text { Crumb } \\
\text { color } \\
15\end{array}$ & $\begin{array}{c}\text { Texture } \\
20\end{array}$ & $\begin{array}{c}\text { Taste } \\
15\end{array}$ & $\begin{array}{c}\text { Flavor } \\
15\end{array}$ & $\begin{array}{c}\text { Over all } \\
\text { acceptabil } \\
\text { ity } \\
100\end{array}$ \\
\hline & Control & $20.0 \mathrm{a}$ & $15.00 \mathrm{a}$ & $15.00 \mathrm{a}$ & $20.00 \mathrm{a}$ & $15.00 \mathrm{a}$ & $15.00 \mathrm{a}$ & $100.0 \mathrm{a}$ \\
\hline \multirow{3}{*}{ in } & Com gluten meal & $15.33 \mathrm{c}$ & $13.33 \mathrm{~b}$ & $12.78 \mathrm{~b}$ & $19.11 \mathrm{ab}$ & $13.28 b c$ & $12.50 \mathrm{c}$ & $86.33 \mathrm{bed}$ \\
\hline & Com fiber & $15.06 \mathrm{c}$ & $13.56 \mathrm{~b}$ & $13.56 \mathrm{~b}$ & $19.59 \mathrm{a}$ & $13.39 \mathrm{bc}$ & $12.33 \mathrm{c}$ & $87.49 \mathrm{bc}$ \\
\hline & $\begin{array}{l}\text { Mix of Com gluten } \\
\text { meal and com fiber }\end{array}$ & $14.57 \mathrm{c}$ & $13.00 \mathrm{~b}$ & $13.28 \mathrm{~b}$ & $19.83 \mathrm{a}$ & $13.11 b c$ & $14.00 \mathrm{~b}$ & $87.79 \mathrm{~b}$ \\
\hline \multirow{3}{*}{ 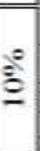 } & Com gluten meal & $14.59 \mathrm{c}$ & $12.94 \mathrm{~b}$ & $13.27 \mathrm{~b}$ & $16.59 \mathrm{cde}$ & $12.72 \mathrm{bc}$ & $12.50 \mathrm{~b}$ & $82.61 \mathrm{~d}$ \\
\hline & Com fiber & $16.66 \mathrm{~b}$ & $12.67 \mathrm{~b}$ & $12.56 \mathrm{~b}$ & $15.48 \mathrm{e}$ & $12.5 c$ & $11.84 \mathrm{c}$ & $81.71 \mathrm{e}$ \\
\hline & $\begin{array}{l}\text { Mix of Com gluten } \\
\text { meal and com fiber }\end{array}$ & $15.45 \mathrm{c}$ & $13.22 \mathrm{~b}$ & $13.44 \mathrm{~b}$ & $16.15 \mathrm{de}$ & $12.67 \mathrm{bc}$ & $12.17 \mathrm{c}$ & $83.10 \mathrm{de}$ \\
\hline \multirow{3}{*}{ 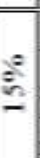 } & Com gluten meal & $14.93 \mathrm{c}$ & $13.33 b$ & $244 b$ & 16.51cde & $12.67 b c$ & $12.17 \mathrm{c}$ & $82.05 \mathrm{e}$ \\
\hline & Com fiber & $15.17 \mathrm{c}$ & $13.00 \mathrm{~b}$ & $12.55 \mathrm{~b}$ & $17.85 \mathrm{bc}$ & $13.28 b c$ & $12.00 \mathrm{c}$ & 83.85 bcde \\
\hline & $\begin{array}{l}\text { Mix of Com gluten } \\
\text { meal and com fiber }\end{array}$ & $15.14 \mathrm{c}$ & $12.89 \mathrm{~b}$ & $12.56 \mathrm{~b}$ & $17.33 \mathrm{~cd}$ & $13.89 \mathrm{ab}$ & $11.84 \mathrm{c}$ & $83.65 \mathrm{cde}$ \\
\hline \multirow{4}{*}{$\hat{\theta}^{2}$} & Com gluten meal & $14.56 \mathrm{c}$ & $12.67 \mathrm{~b}$ & $12.5 b$ & 15.89 de & $12.13 \mathrm{c}$ & $12.06 \mathrm{c}$ & $79.87 \mathrm{e}$ \\
\hline & Com fiber & $14.68 \mathrm{c}$ & $12.5 b$ & $12.78 \mathrm{~b}$ & 15.71de & $13.22 \mathrm{c}$ & $12.33 \mathrm{c}$ & $81.22 \mathrm{e}$ \\
\hline & $\begin{array}{l}\text { Mix of Com gluten } \\
\text { meal and com fiber }\end{array}$ & $15.28 \mathrm{c}$ & $13.06 \mathrm{~b}$ & $12.56 \mathrm{~b}$ & 16.41cde & $13.06 \mathrm{bc}$ & $12.26 \mathrm{c}$ & $82.63 \mathrm{de}$ \\
\hline & L.S.D. & 1.02 & 0.85 & 1.18 & 1.65 & 1.33 & 0.95 & 4.11 \\
\hline
\end{tabular}

Dough prepared with 5 and $10 \%$ substitution level of corn gluten meal, corn fiber, and mix of them were extremely similar to control in consistency and handling characteristics. The water absorptive properties showed 
gradually increase with raising the substitution levels of wheat flour with corn fiber and mix of (corn fiber \& corn gluten meal) blends, thus, these dough were much drier and more firm than the control, and therefore, it was more difficult to shape and handle.

Results of sensory quality evaluation show that all organolyptic attributes of pan bread produced from different levels of corn gluten meal, corn fiber, and mix of them wheat flour substitution were significantly affected by these substitution. The overall acceptability was decreased with each increment of wheat flour replacement with corn gluten meal, corn fiber, and mix of them. Devin, et al., (2010) reported that research on the utilization of corn-milling co-products in food products began with the addition of corn bran to breads, cakes and muffins with the aim of increasing the dietary fiber content of widely consumed foods. Unfortunately, this resulted in undesirable changes in product quality: bread containing corn bran at $200 \mathrm{~g} \mathrm{~kg}-1$ flour showed a $20 \%$ reduction in loaf volume, layer cakes containing corn bran at $300 \mathrm{~g} \mathrm{~kg}-1$ flour showed decreases in most sensory scores, including texture, color and flavor and corn bran at $250 \mathrm{~g} \mathrm{~kg}-1$ flour in muffins resulted in significant decreases in flavor, mouth feel, texture and overall acceptability compared with muffins containing the same level of wheat bran.

Pan bread prepared with substitution levels $20 \%$ of corn gluten meal and corn fiber had the lowest scores of all organolyptic attributes. All samples of pan bread from flour blends were ranged from good to satisfactory. Similar results were obtained by Sharma, et al., (2012), who reported that blending of corn bran, defatted germ and gluten at 5 and $10 \%$ with wheat flour resulted in satisfactory bread, cookie, and muffin score. 
4- Physical measurements: Pan bread samples were subjected to physical measurements including weight, volume, and specific volume. Measurements of flour substituted pan bread at various levels are shown in table (5).

Table(5): Effect of addition corn gluten meal, corn fiber, and mix of them on physical properties of pan bread

\begin{tabular}{|c|c|c|c|c|c|}
\hline & Addition percent & Weight & $\begin{array}{c}\text { Volum } \\
\text { e }\end{array}$ & Density & $\begin{array}{l}\text { Specific } \\
\text { volume }\end{array}$ \\
\hline & Control & 108.27 & 410 & 0.27 & 3.79 \\
\hline & Corn gluten & 111.1 & 295 & 0.38 & 2.66 \\
\hline $5 \%$ & Corn fiber & 113.0 & 295 & 0.38 & 2.61 \\
\hline & $\begin{array}{l}\text { Mix of Corn gluten and } \\
\text { corn fiber }\end{array}$ & 110.64 & 383.75 & 0.29 & 3.47 \\
\hline & Corn gluten & 113.21 & 318.75 & 0.36 & 2.82 \\
\hline $10 \%$ & Corn fiber & 112 & 376.25 & 0.30 & 3.36 \\
\hline & $\begin{array}{c}\text { Mix of Corn gluten and } \\
\text { corn fiber }\end{array}$ & 113.06 & 371.25 & 0.31 & 3.29 \\
\hline & Corn gluten & 114.21 & 287.5 & 0.40 & 2.52 \\
\hline $15 \%$ & Corn fiber & 112.08 & 278.75 & 0.40 & 2.49 \\
\hline & $\begin{array}{c}\text { Mix of Corn gluten and } \\
\text { corn fiber } \\
\end{array}$ & 111.04 & 318.75 & 0.35 & 2.87 \\
\hline & Corn gluten & 113.38 & 281.25 & 0.41 & 2.48 \\
\hline $20 \%$ & Corn fiber & 111.82 & 221.25 & 0.51 & 1.98 \\
\hline & Mix of protein and fiber & 112.65 & 266.25 & 0.42 & 2.37 \\
\hline & L.S.D. & 0.83 & 6.29 & 0.004 & 0.063 \\
\hline
\end{tabular}

Results indicated that specific volume (which relates with good texture) of wheat flour substituted pan bread samples was lower than that of control sample. A negative relationship could be noticed between flour substitution level and pan bread specific volume. Pan bread specific volume of control 104 
sample was $3.79 \mathrm{~cm}^{3} / \mathrm{gm}$ and ranged from 2.61 to $3.47 \mathrm{~cm}^{3} / \mathrm{gm}$, from 2.82 to $3.36 \mathrm{~cm}^{3} / \mathrm{gm}$, from 2.49 to $2.87 \mathrm{~cm}^{3} / \mathrm{gm}$, and from 1.98 to $2.48 \mathrm{~cm}^{3} / \mathrm{gm}$ for pan bread samples containing wheat flour replacement at levels 5, 10, 15 and 20\% of corn byproducts (corn gluten meal, corn fiber, and mix of them), respectively. Similar results were obtained by Devin, et al., (2010) reported that bread containing corn bran at $200 \mathrm{~g} \mathrm{~kg}-1$ flour showed a $20 \%$ reduction in loaf volume.

5- Chemical composition: The chemical composition of pan bread produced from wheat flour and blends of wheat flour with replacement at levels 5, 10, 15 and $20 \%$ of corn byproducts (corn gluten meal, corn fiber, and mix of them), are presented in table (6) and figures (1and 2) 
J. Environ. Sci.

Institute of Environmental Studies and Research - Ain Shams University

Table (6): Chemical composition of pan bread produced by substituted wheat flour $72 \%$ ex. (WF) with $5,10,15$ or $20 \%$ corn gluten meal, corn fiber, and mix of them.

\begin{tabular}{|c|c|c|c|c|c|c|c|c|}
\hline \multirow[b]{2}{*}{ Samples } & & \multirow[b]{2}{*}{$\begin{array}{c}\text { Energy } \\
\text { cal./100gm On } \\
\text { dry weight } \\
\text { basis }\end{array}$} & \multirow[b]{2}{*}{$\begin{array}{c}\text { Moisture } \\
\%\end{array}$} & \multicolumn{5}{|c|}{ As a dry basis } \\
\hline & & & & $\begin{array}{c}\text { Protein } \\
\%\end{array}$ & $\begin{array}{c}\text { Fat } \\
\%\end{array}$ & $\begin{array}{c}\text { Total } \\
\text { dietary } \\
\text { fiber } \\
\%\end{array}$ & $\underset{\%}{\text { Ash }}$ & $\begin{array}{c}\text { Total } \\
\text { carbohydrate } \\
\%\end{array}$ \\
\hline Control & & 395.66 & 30.53 & 11.13 & 2.70 & 2.79 & 1.67 & 81.71 \\
\hline $\begin{array}{l}95 \% \mathrm{WF}+5 \% \\
\text { corn gluten meal }\end{array}$ & & 396.68 & 30.62 & 13.41 & 2.92 & 2.76 & 1.72 & 79.19 \\
\hline $\begin{array}{l}\% \text { change from } \\
\text { control }\end{array}$ & & 0.26 & 0.29 & 20.50 & 8.15 & -1.10 & 2.99 & -3.08 \\
\hline $\begin{array}{l}95 \% \mathrm{WF}+5 \% \\
\text { corn fiber }\end{array}$ & & 386.59 & 31.34 & 10.99 & 2.83 & 5.07 & 1.82 & 79.29 \\
\hline $\begin{array}{l}\% \text { change from } \\
\text { control }\end{array}$ & in & -2.29 & 2.65 & -1.26 & 4.81 & 81.72 & 8.98 & -2.96 \\
\hline $\begin{array}{l}95 \% \text { WF }+5 \% \\
\text { mix of gluten \& } \\
\text { fiber }\end{array}$ & & 391.64 & 31.00 & 12.2 & 2.88 & 3.92 & 1.77 & 79.23 \\
\hline $\begin{array}{l}\% \text { change from } \\
\text { control }\end{array}$ & & -1.02 & 1.54 & 9.61 & 6.70 & 40.50 & 5.99 & -3.04 \\
\hline $\begin{array}{l}90 \% \mathrm{WF}+10 \% \\
\text { corn gluten }\end{array}$ & & 397.85 & 31.40 & 15.70 & 3.14 & 2.72 & 1.76 & 76.68 \\
\hline $\begin{array}{l}\% \text { change from } \\
\text { control }\end{array}$ & & 0.55 & 2.85 & 41.10 & 16.30 & -2.51 & 5.39 & -6.16 \\
\hline $\begin{array}{l}90 \% \mathrm{WF}+10 \% \\
\text { corn fiber }\end{array}$ & & 377.65 & 32.17 & 10.85 & 2.97 & 7.34 & 1.96 & 76.88 \\
\hline $\begin{array}{l}\% \text { change from } \\
\text { control }\end{array}$ & 0 & -4.55 & 5.37 & -2.52 & 10.0 & 163.1 & 17.37 & -5.91 \\
\hline $\begin{array}{l}90 \% \text { WF }+10 \% \\
\text { mix of gluten } \\
\& \text { fiber }\end{array}$ & & 387.69 & 31.80 & 13.28 & 3.05 & 5.03 & 1.86 & 76.78 \\
\hline $\begin{array}{l}\% \text { change from } \\
\text { control }\end{array}$ & & -2.01 & 4.16 & 19.32 & 12.96 & 80.30 & 11.38 & -6.03 \\
\hline
\end{tabular}


ConTable (6):

\begin{tabular}{|c|c|c|c|c|c|c|c|c|}
\hline \multirow[b]{2}{*}{ Samples } & & \multirow{2}{*}{$\begin{array}{c}\text { Energy } \\
\text { cal./100gm } \\
\text { On dry } \\
\text { weight } \\
\text { basis }\end{array}$} & \multirow[b]{2}{*}{$\begin{array}{c}\text { Moisture } \\
\%\end{array}$} & \multicolumn{5}{|c|}{ As a dry basis } \\
\hline & & & & $\begin{array}{c}\text { Protein } \\
\%\end{array}$ & $\begin{array}{c}\text { Fat } \\
\%\end{array}$ & $\begin{array}{c}\text { Total } \\
\text { dietary } \\
\text { fiber } \\
\% \\
\end{array}$ & $\begin{array}{c}\text { Ash } \\
\%\end{array}$ & $\begin{array}{c}\text { Total } \\
\text { carbohydrate } \\
\%\end{array}$ \\
\hline $\begin{array}{l}85 \% \mathrm{WF}+15 \% \\
\text { corn gluten }\end{array}$ & \multirow{6}{*}{ i̊ } & 398.83 & 31.40 & 17.98 & 3.35 & 2.69 & 1.79 & 74.19 \\
\hline $\begin{array}{l}\% \text { change from } \\
\text { control }\end{array}$ & & 0.80 & 2.85 & 61.55 & 24.10 & -3.58 & 7.20 & -9.20 \\
\hline $\begin{array}{l}85 \% \mathrm{WF}+15 \% \\
\text { corn fiber }\end{array}$ & & 368.61 & 33.10 & 10.71 & 3.09 & 9.62 & 2.09 & 74.49 \\
\hline $\begin{array}{l}\% \text { change from } \\
\text { control }\end{array}$ & & -6.84 & 8.42 & -3.77 & 14.44 & 244.8 & 25.15 & -8.84 \\
\hline $\begin{array}{l}85 \% \mathrm{WF}+15 \% \\
\text { mix of gluten } \\
\& \text { fiber }\end{array}$ & & 383.75 & 32.30 & 14.34 & 3.23 & 6.15 & 1.95 & 74.33 \\
\hline $\begin{array}{l}\% \text { change from } \\
\text { control }\end{array}$ & & -3.00 & 5.80 & 28.84 & 19.63 & 120.43 & 16.77 & -9.03 \\
\hline $\begin{array}{l}80 \% \mathrm{WF}+20 \% \\
\text { corn gluten }\end{array}$ & \multirow{6}{*}{ :̊ } & 399.81 & 32.04 & 20.25 & 3.57 & 2.67 & 1.84 & 71.67 \\
\hline $\begin{array}{l}\% \text { change from } \\
\text { control }\end{array}$ & & 1.05 & 4.95 & 81.94 & 32.22 & -4.30 & 10.18 & -12.30 \\
\hline $\begin{array}{l}80 \% \mathrm{WF}+20 \% \\
\text { corn fiber }\end{array}$ & & 359.67 & 33.28 & 10.57 & 3.23 & 11.88 & 2.24 & 72.08 \\
\hline $\begin{array}{l}\% \text { change from } \\
\text { control }\end{array}$ & & -9.10 & 9.00 & -5.03 & 19.63 & 325.81 & 34.13 & -11.79 \\
\hline $\begin{array}{l}80 \% \mathrm{WF}+20 \% \\
\text { mix of gluten } \\
\& \text { fiber }\end{array}$ & & 379.72 & 33.00 & 15.42 & 3.40 & 7.28 & 2.04 & 71.86 \\
\hline $\begin{array}{l}\% \text { change from } \\
\text { control }\end{array}$ & & -4.03 & 8.09 & 38.54 & 25.93 & 160.93 & 22.16 & -12.10 \\
\hline
\end{tabular}

From the previous results in Table (6) and figures (1) and (2) it could be concluded that the chemical composition and caloric values of pan bread produced from substitute wheat flour with 5, 10, 15 and $20 \%$ corn gluten meal, corn fiber, and mix of them blends are differed from control by differ flour substitution level.

Results showed that protein content of pan bread was increased from $11.13 \%$ for control sample to $13.41,15.70,17.98$ and $20.25 \%$ for pan bread 
with $5,10,15$ and $20 \%$ corn gluten meal, respectively and to $12.12,13.28$, 14.34 and $15.42 \%$ for pan bread with mix of (corn gluten meal+ corn fiber) at replacement levels 5, 10, 15 and 20\%, respectively. Whereas, the protein content of pan bread was decreased for 10.99, 10.85, 10.71 and $10.57 \%$ for pan bread with corn fiber at replacement levels 5, 10, 15 and 20\%, respectively.

Protein content increment (compared to control) percentage ranged from 20.5 to $81.9 \%$ for corn gluten meal and from 9.61 to $38.54 \%$ for mix of (corn gluten meal+ corn fiber) at replacement levels ranged from 5 to $20 \%$, respectively. While protein content percentage decreased (compared to control) from -1.26 to $-5.03 \%$ for pan bread with replacement levels ranged from $5-20 \%$ corn fiber.

From the same results it could be noticed that fat contents of pan bread (compared to control sample) increased from 8.15 to $32.22 \%$ for corn gluten meal, from 4.81 to $19.63 \%$ for con fiber and from 6.7 to $25.93 \%$ for mix of (corn gluten meal+ corn fiber) at replacement levels ranged from 5 to $20 \%$, respectively.

The increment in total dietary fiber contents (compared to control) percentage ranged from 81.72 to $325.81 \%$ for corn fiber and from 40.5 to $160.93 \%$ at replacement levels ranged from 5 to $20 \%$, respectively.

Ash contents increased (compared to control) by percentage ranged from 2.99 to $34.13 \%$ by differ the types and levels of replacement.

It could be noticed that protein, fat, total dietary fiber and ash contents of pan bread increased by increasing the level of replacement of wheat flour 
with mix of (corn gluten meal+ corn fiber), this mainly due to high content of these components in the replacing ingredients.

From the same results it could be noticed that total protein content increased by about 1.2 to 1.82 times like control, by replacing wheat flour with 5 to $20 \%$ corn gluten meal, whereas, total dietary fiber increased by about 1.82 to 4.26 times like control by replacing wheat flour with 5 to $20 \%$ corn fiber. Similar results were obtained by Sharma, et al., (2012), who reported that blending of wheat flour and corn byproducts significantly increased the protein, crude fiber, phosphorus, iron and calcium contents.

\section{REFERENCES}

A.A.C.C. (2000). American Association of Cereal Chemists, methods 54-21, In : Approved Methods of The American Association of Cereal Chemist, The Association, St. Pull, MN., USA.

AOAC (2005). Official Methods of Analsis of the AOAC International 18thed.Maryland,USA.PP.1-32.

Davis,R.(2009). Corn gluten meal as complex carb,fiber or protein. http:www.vonlobos.com.

Devin; J. R.; George E I. and Sean X. L. (2010): Utilization of corn (Zea mays) bran and corn fiber in the production of food components. $J$ Sci Food Agric 2010; 90: 915-924.

Dougherty , M.; R.Sombk; J. Lrvine and C.S. Rao (1988). Oat fiber in low calorie breads, soft type cookies and pasta. Cereal Foods World, 33: 424-427.

Erickson, A. (2006). Corn wet milled feed products. Corn Refiners Association $701 \quad$ Pennsylvenue,N.W.Washington,D.C. www.com.org 
Food and Drug Administration Center for Food Safety \& Applied Nutrition Office of Food Additive Safety (2010) :Division of Biotecqnology and GRAS Notice Review. December 22, 2010. mcquate@gras-associates.com ,www.gras-associates.com

Gaspar, M., Kalman, G., Reczey, K. ,2007. Corn fiber as a raw material for hemicelluloses and ethanol production, J. Anim. Sci. 51, 11351139 .

Hill,D.A. (2004). Alternative proteins in companion animal nutrition. Ph.D., P.A.S.., D.A.C.A.N. ADM Animal Health \& Nutrition. QUINCY, IL,USA 62301. http://www.Fao.Org

Hills, F.J. (1966):Experimental design and statistical analysis In: Experimental method for extension workers. Agriculture extensive Service. University of California, Section II.

Ibrahim, M. A. (2011)"Chemical and biological studies on some bakery products" Ph.D. thesis Agric. Sci. Agric. Fac., Moshtohor, Zagazig University, Banha Branch (2011)

Inglett, G.E., 2005. Dietary fiber gels for calorie reduced foods and method for preparing the same. U.S. Patent 5,766,662 filed Nov. 28,1995 and issued June 16,1998.

Minnesota Nutrition Conference: Minnesota Corn Growers Association Technical Symposium, September 11, 2001.

Nasr, H.M. (2012). Biochemical studies on some industrial wastes. Ph.D. Thesis, Agricultural Biochemistry, Dept., Faculty of Agric., Cairo Univ., Egypt

Polizotto LM, Tinsley AM, Weber CN, Berry JW (1983) Dietary fiber in muffins. J Food Sci 48(1):111-113.

Sharma, S.; Gupta, J. P.; Nagi, H. P. S. and Kumar, R. (2012): Effect of incorporation of corn byproducts on quality of baked and extruded products from wheat flour and semolina. J. Food Sci. Tech. (September-October 2012) 49(5):580-586. 
Uthayakumaran, S.; Gas., P.W.; Stoddard, F.L. and Bekes, F. (1999). Effect of varying protein content and Gelatenin-Gliadin Ratio Cereal Chem., 76 (3): 389-394.

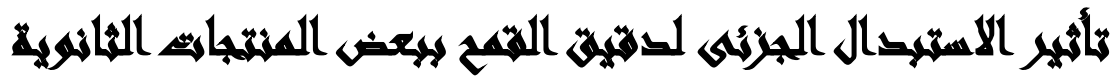

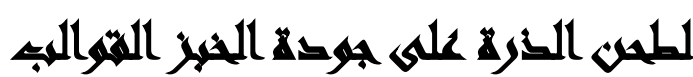

[7]

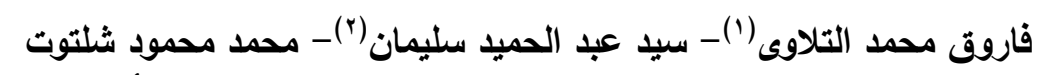

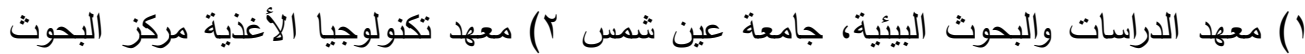
الزراعية

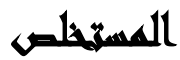

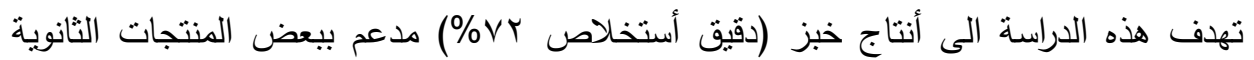

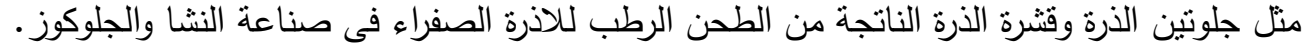

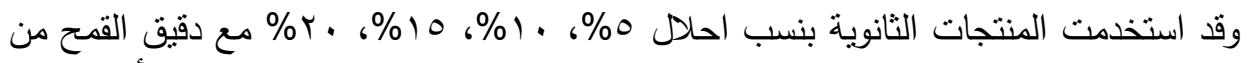

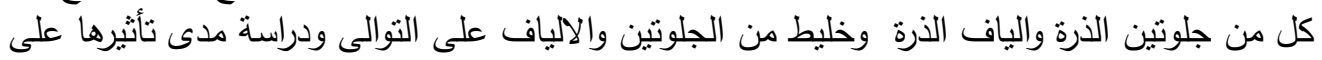

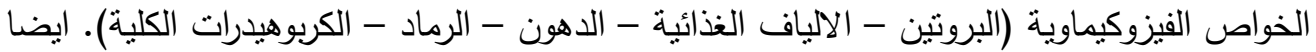

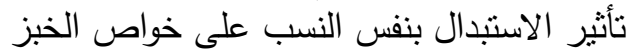

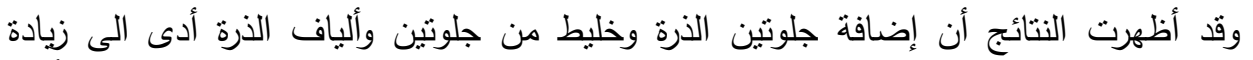

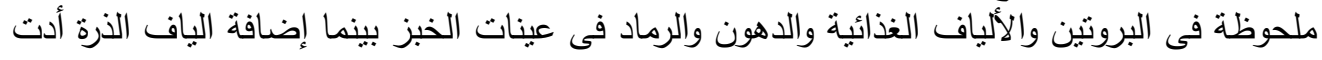

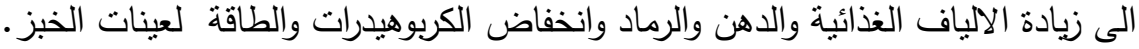

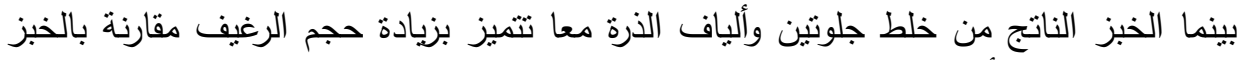

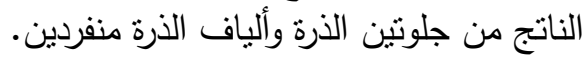
الكلمات المفتاحية: قشرة الذرة - جلوتين الذرة - دقيق الذين القمح - الطحن الرطب للذرة 